\title{
Aesthetics and functions of craft art in public art space
}

\author{
${ }^{\otimes}$ Alvi Lufiani, Setiawan Sabana, Achmad Haldani
}

\author{
Postgraduate Program, Institut Teknologi Bandung, Indonesia
}

Received: April 1, 2017. Revised: May 15, 2017. Accepted: May 29, 2017

\begin{abstract}
The problem in this research is about how to assess the aesthetics and functions of craft art in Indonesian city public space compare to other cities in other countries. It is also about how these craft arts can be used to improve the aesthetics and strength a city's identity. Approaches used in this research are aesthetic theory and sociology of art. Aesthetic theory is used to assess the craft art textually or intra aesthetics. Sociology of art theory is used to see how craft art role can fulfil its function as a medium for craftsperson to participate in creating an art work that is useful to the society, so the existence of craft art in public space can give positive impacts towards the urban society. Results of this research is a positive impact of the craft art existence in some Indonesian public places where craft art becomes a city icon or identity with a special symbol attached to it; as a sign of historical or contemporary works. It also creates the aesthetics of a city design to be more humanist and healthy for all citizens.
\end{abstract}

Keywords: craft art; aesthetics; public space; urban society

How to Cite: Lufiani, A., Sabana, S., \& Haldani, A. (2017). Aesthetics and functions of craft art in public art space. Harmonia: Journal of Arts Research And Education, 17(1), 41-47. doi:http:/ /dx.doi.org/10.15294/harmonia.v17i1.7469

\section{Introduction}

Historically, craft art was developing from the humans' necessity to get along with their environment. This necessity becomes more developed since there was a kingdom influence that wanted the craft art product to be used not only as a tool that had practical function, but also had aesthetic, artistic, philosophic, and symbolic functions. Art work was also used as a sign of social status like what they had in jewellery, Kris (Indonesian special traditional sword), or batik. As widely known by Indonesian people, every Kris created by a Kris master has plenty of philosophies which is represented by its pamor (fame) contained in numbers of luk, shape of the warangka, and etc.
Rohidi (2015) stated that craft art is reflected the culture and geography of where those crafts are being created. It means that in the process or technic of making that craft art, shape of the work, and the use of that work, there is a reflection of beauty values, moral, and thought that become a reference for the maker and also being a natural-physic environmental resources and social culture that can be used by the creator. As time goes by, craft art was also facing the change that gives impact to the craft art that is being created. In the west part of the world, there are some terms used by the craft-person/ craft-people to explain about their craft art that they do. There are contemporary craft, new craft, studio craft, craft object, and other terms of crafts. The main idea is that craft art that

\footnotetext{
${ }^{\square}$ Corresponding author: Jl. Ganesha No.10, Lb. Siliwangi, Coblong, Kota Bandung, Jawa Barat 40132

E-mail: alufiani1@gmail.com
} 
is being made is not only used to fulfil the primary needs of human living, but it has already upheld the importance of aesthetic and artistic values that sometimes overrides the practical functional aspects. As stated by Tjetjep, besides the function to fulfil the social need, the creation of craft art is also used to fulfil cultural need. For instance, the creation and selection of good craft art supports one or group's prides and dignity. As in kris example above, one's social status, especially from Javanese ethnics, is often determined from the kris collection that he has. The same rule is also applied in batik. Until now, there are some kinds of batik that only can be owned and wore by the kingdom members.

In Indonesia, the society knows craft art as a product of a handicraft and has strong relation with everything that has ethnical value. The term of contemporary craft is sometimes still unfamiliar to most people because they are accustomed to associate it with pure art. Only in some big cities that has strong culture like Jakarta, Bandung, Surabaya, and Yogyakarta that the society will know and understand that the shape and variety of the modern craft art is different from the old craft art. It is also influenced by the existence of schools and arts colleges that influence the surrounding community a bit more to be literate on the latest work of craft art.

In Yogyakarta, one of the art work centre in Indonesia, craft art created by the craft-person is still in the form of existing traditional craft art concept. Till recent days, arts shown in public places of this city (as in other big cities in Indonesia as well), is dominated by pure art work, like, statue, or street art as in mural and graffiti.

The existence of craft art in urban places can be categorized into a new phenomenon not only in Yogyakarta, but also in other big cities in Indonesia. This is interesting since in other countries craft art as an element in public place is a common thing. It can attract people attention and usually get very positive respond. In Osaka, Japan, the city government often works together with the artists or craft per- sons to create a craft work to be placed in city's public place. It is definitely having a lot of requirements that should be fulfilled by the craft-persons, so their works are suitable to be placed in the public place and become a public property along with the consequences.

Some of the requirements are that the art works should have connection with the public places and not ahistorical. It also needs to be able to become a representative or a city symbol, able to be accessed by its people easily, able to be used as an interaction tool among citizens, able to bring many benefits, able to minimize chaos, etc. As stated by Jack Berker in Public Art Monograph that placing an art work or statue in a public place is not the same as planning an art work that will be placed in a specific place since the audiences' aspects, environmental condition and history of the place have to be considered (Baker, 2010).

Thus, it can be understood that to put an art work, whether it is craft art or pure art, a serious consideration and good cooperation among all sides are needed to be done. These considerations comprise intra aesthetic perspective or textual and extra aesthetic or contextual, in this case is the function of an existing craft work. Therefore, the the problem to be discussed in this paper is how to determine the aesthetics and functions of craft work placed in public place of several cities in Indonesia compared with other cities of other countries, and also how this craft art can improve the aesthetics and strengthen the identity of a city.

\section{Method}

Approach and method employed in this study, respectively, are cultural study and interdisciplinary. Operationally, this approach and method place the culture as a form of behaviour, attitude, idea, and work of the society as something that is dynamic, routine, and complex. Therefore, culture cannot be understood in mono discipline perspective (Puspitasari, 2016, p. 58). Aesthetic theory and sociology of 
art are used to discuss craft art in public space. Sociology of art theory is then used to see what is the role of craft art to fulfil its function. Among the functions are as a medium for craft-person to participate in creating work that will be useful for all society. The implication is that the existence of the craft art can give a positive impact on the urban society. This is in line with Wellek and Warren in Jazuli who stated that one of the sociology of art approach is an evaluation of social influence in art work, especially from the audience perspective (Jazuli, 2014, p. 25).

\section{Results and Discussion}

Gordon and Knox, director of Arizona State University of Art Museum in his writing Crafting a Continum: What is Enduring in Craft? What is its Future?(tahun?) stated that as in language, art and craft related to the society. Craft relates with society from its relation to the object and more frontal making process compares to the pure art. The main difference of the making process in craft may become one thing that differentiates craft with pure art. However, the relation and similarity between craft art and pure art become more important in relation to their similarity (in their relations with the society), as in expression, idea and aesthetic exploration. Knox emphazises that either craft art or pure art have a strong relation between them and more important, with the society.

Those factor of relation and interest to the society at the end will become one thing that cannot be separated from art work and its application in public place in the city. The reason is that at the end, the society should and will get the most benefits from the existence of an art work in the public space. Of course, there are various factors that will define the success level, one of that is aesthetic or artistic value in the art work.

Craft art in the public place of a city at least expected to be improving the dialogue between community and citizens, call the attention of the society and stimulate economy sector, relate the artists, craftperson and society, and improving public appreciation to the craft art (Berker, 2010).

In addition to this, Berker added that, from art work in public place, a craft-person could directly deliver his/her message to the public, without using an art gallery mediator or other media. Creative expression that they have can be sent to everyone started from an executive, downtown citizens, suburbs, children, teenagers, elderly, city government, common people, and other people. Therefore, a craft work in a public place has democratic character since it comes from, by and for the society.

Craft art that will be discussed in this paper will use aesthetic theory to determine its textual side. Based on Dick Hartoko, aesthetic is from Greek aesthetis means perception, experience, feeling, and view. Baumgarten, a Germany philosopher used it for the first time to refer to a philosophy branch that has a relation with art and beauty. Based on him, there are two kinds of beauty, the objective and subjective beauty. Subjective because the beauty is in the human mind and objective since it is outside of human mind, as in situation or thing. The differences are on the beauty of nature and beauty of human making things that contained on an art work. Craft art is object making by a human that contained in an art work. Craft art is an object created by a human that has objective aesthetic value (Hartoko, 1984, p.15).

The first craft art to be discussed is an art phenomenon from Miami, the US, created by a craft-person Kim Brandell. Kim's work categorizes as street furniture, that has one strong craft characteristic that is a bench that is practically functional. One of Kim's famous work is a bench located in Miami Coconut Grove, a city park in the city centre of Miami, Florida. From the textual side, this bench is artistic, since in the place to sit there is a piece of leave and that bench looks as if it is sustained by a coconut tree that also has functioned as a shade since Miami is well known of its sun shines. This place is different from other states in the US. The bench, in addition, is 
made from stainless steel, so it looks strong and long last, safe to be seated by people with different sizes, even it does not have a problem if it is stood by the children. The selection of grey colour for the bench is intended to give the futuristic and neutral impression to the surrounded area. It is an interesting juxtapose, since from the colour side, that bench looks futuristic, but from the shape side it is all look naturalistic.

The coconut shape choice for the bench sustain makes the bench the icon of Miami. Miami itself is famous for the beauty of the beach completed with the coconut tree and the city is decorated with palm tree that lined up neatly as if it welcomes every citizen and every people coming there. Looking at Kim's bench, people will understand and directly associate it with the icon of the city of Miami. Citizens are happy with the bench and visitors usually use it as a property to have a picture. Placement of bench in Miami Coconut Grave city park also a thing that had already thought carefully, since this place becomes a place that is always visited by the citizens or visitors. The size of palm bench that can be occupied by three people makes it be one of the citizen media to do interaction. They could talk and become closer even if they had not known each other before.

Kim's palm bench is a craft work that fulfils the requirement as an ideal public place craft work. Visually, it looks artistic and can be a representation of a city identity. Palm bench also has function as a bench that is safe and comfortable to be seated and used for children to play. Palm bench as a street furniture becomes a part of design element vocabulary that widen the concept of a place or room. As stated by Ronald Lee Fleeming in The Art of Placemaking, Interpreting Community Through Public Art and Urban Design that sometimes a street furniture work can be associated strongly with a city that when it becomes the symbol of its city (Ronald, 2007, p. 246). Palm bench has been a success in doing its job; as a representation of city interaction and fulfil its function as an interaction medium among the citizens.

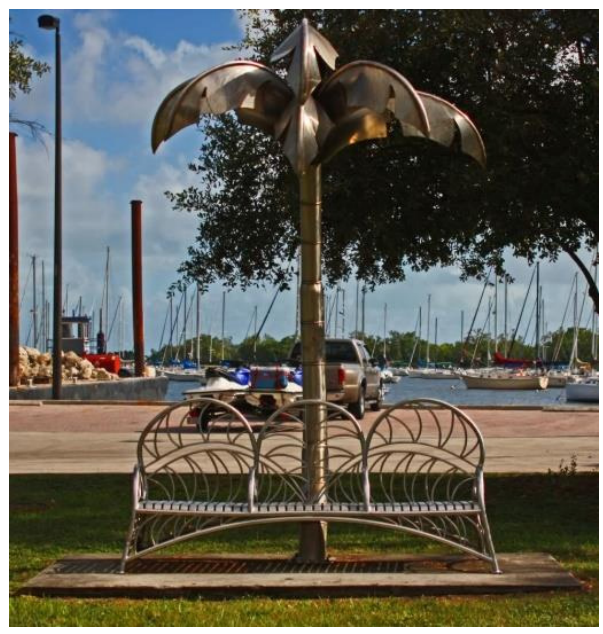

Figure 1. Palm Bench, created by Kim Brandell in Miami Coconut Grove, Florida, US (Source: The Art of Placemaking: Interpreting Community Through Public Art and Urban Design).

Craft work which has existed in other country's public area is not only street furniture, or art work that has practical functions only. There are many craft works that can attract society attention since it is prominence with the craftsmanship side that is applied to that work besides, of course, its functions for the public.

An art work that should not be neglected is a phenomenal art work by an architect who is also an artist from India named Sanjeev Shankar. From the side of its making process, it needs deep patience. This work can be classified as a craft work. Sanjeev creates an art work entitled $J u$ gaad, coming from Hindi and refer to how to create an object using materials which is available around us. Jugaad is a canopy, or roof protection which is made from waste cooking oil tins. Around less than three months, these tins are optimized as a media to explore an idea about sustainability, recycle and reuse by using the help from 90 citizens of Rajokri, a suburban of New Delhi, India. Around 945 old tins are processed and become a 70 meters square canopy. The canopy firstly showed to the public at the art festival in New Delhi in 2008 with Goethe Institute and German Technical cooperation (www.sanjeevshankar.com) as the sponsor.

Jugaad attracts public attention as 
well as many awards from art institution and architecture in England and the US. The creator, Sanjeev said that global issues like recycle, reuse, reduce or sustainability only can touch the society, especially the low-class society, if it is connected directly with their daily life. If not, this thing will only be an imagination and just a rhetorical. Through the deep involvement, there is a change of perspective from the society and they see the benefits from the project that is worked. Citizens also see the big potential from something that has been used before and only becomes a trash. As the time goes by, almost all of the community is influenced to use the old stuff (cooking oil tin), making the object to another product that has value and is useful. Patiently, citizens are involved in Jagaad making process started from collecting, cleaning, drilling, painting and uniting every part of tin into one.

From the aesthetic side, Jugaad also looks unique and harmony because of its neat composition between one part. The colour is used, that is pink on the top and sorrel in the bottom also supports it. Colour material used is from a traditional material named gulal that usually applied in the colour festival Holi in India. The craft work becomes more interesting and loved by the citizens when it is blown by the wind. The canopy will move beautifully and looks like it is flying slowly. It also produces a rhythmic sound. It is really a combination of art work that is not only functional, but also satisfying for the eye and ear of the audiences. It is interesting on how an architect and craft-person like Sanjeev is optimizing the use of old material, traditional colour maker and citizens to work hand in hand in creating a work that is not only artistic, economical, but also functional

The benefit of this Jugaad canopy is also felt by whole society. The temperature in New Delhi that usually reaches up to 40 degrees in the afternoon, makes the society feels how comfortable it is to put their shelves under the canopy. At night, Jugaad is very artistic and attracts people to enjoy its lights. Here, Jugaad is a proof and combination of society effort in creativity and improvisation when they are making use of old stuff to be useful in valuable in the middle of the arising of consumptive culture. Jugaad project indicates the starting point of simple into radical steps of designing a public room for the community by upholding the spirit of democracy. From the perspective theory of sociology of art, Jagaad can be categorized as a success in creating social interaction between society or citizen by being facilitated by the work. As explained by Wadiyo (2006, p. 1) that if an art work is able to create action and reaction between the creator and appreciator, social interaction also automatically will happen. Below are some pictures of Jagaad, from its visualization in the afternoon and night, the process of collecting the materials, and until the making process.

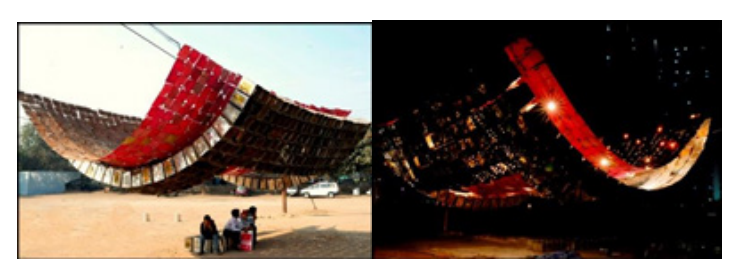

Figure 2 \& 3 . Jagaad canopy in the afternoon and evening by Sanjeev Shankar (Source: www.sanjeevshankar.com/jugaad).

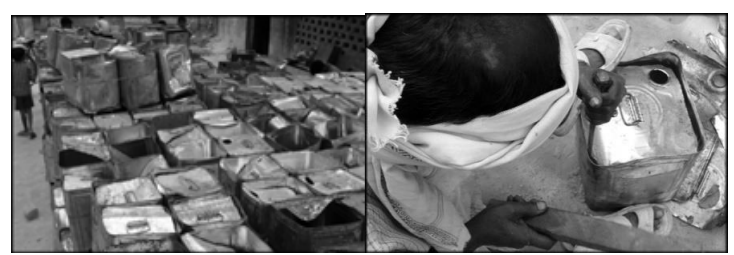

Figure $4 \& 5$. Process of collecting and cleaning the wasted tins

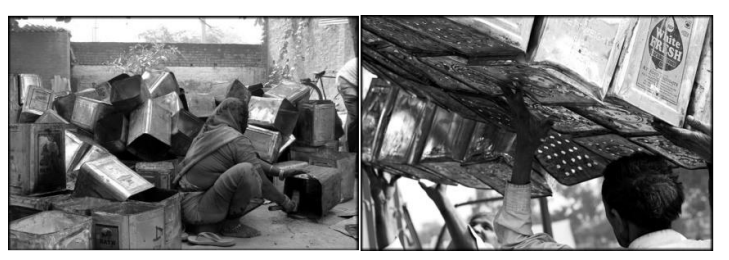

Figure $6 \& 7$. Citizens are opening the tins' cover to put the colours and assemble the parts of the tin to be one as a canopy. (Source: www.sanjeevshankar.com/jugaad).

Indonesia has a different situation. 
Even if Indonesia has strong traditional craft art, the reality showed that there is no -or not yet- many craft works that we can find, if it is compared to other countries. One of the aspects influencing this is because the art placed in the public area usually are dominated by the pure art like a statue. It is also influenced by society understanding on the perception that craft art is usually a small object with mass production and not to be used to be placed in public area. Craft art made by the craft-person in Indonesia generally is made as a filler or interior element of a room or other small needs.

Yogyakarta as a centre of art and culture becomes the pioneer by starting the tradition of outdoor craft art. It is initiated by Timbul Raharjo, a craft-person, academics and also a businessman with craft work entitled Kuda Egrang. This Kuda Egrang can be stated as a phenomenal craft art since it is a topic of conversation, discussion, and debate which is quite debatable among artists, humanist, curator and Yogyakarta society. Some of them actually do not care if the works are categorized as craft work, but what makes it interesting is that how society responds to Kuda Egrang as the art object from their own perspectives and their opinion towards this work; whether it can fulfil its function as an art work that represented Yogyakarta as a city of art and culture (Lufiani, 2016).

Aesthetically, Kuda Egrang looks attractive with the use of hundred iron pipes which is cut in relatively similar small sizes. The pieces of these pipes then being placed on an iron frame that has been made to sustain the kuda egrang. Setting that has been made neatly showed the high artistic from the craft work of kuda egrang. Kuda Egrang, even if it not fully represents or becomes an identity of Yogyakarta, still becomes one of the icons of a city with strong Javanese culture. In Javanese culture, there is a requirement that should be fulfilled by someone so he can be a knight, here is Javanese knight. Five requirements to be Javanese knights are Wisma, Turangga, Kukila, Waspada, and Wanita.
The second requirement is turangga which means horse. In the old time, the horse is a daily transportation, so it is functioning as a vehicle or "tungganggan". Nowdays, turangga can be translated as a permanent job since it becomes one of the requirements for a man who wants to be respected in the family. This Javanese philosophy then becomes the basic thought of Timbul Raharjo in creating Kuda Egrang as an outdoor craft work that does not only have aesthetic, but also philosophical meaning especially in Javanese philosophy (personal interview with Timbul Raharjo). In this case, Kuda Egrang represents identity symbol of Yogyakarta that is based on Javanese culture.

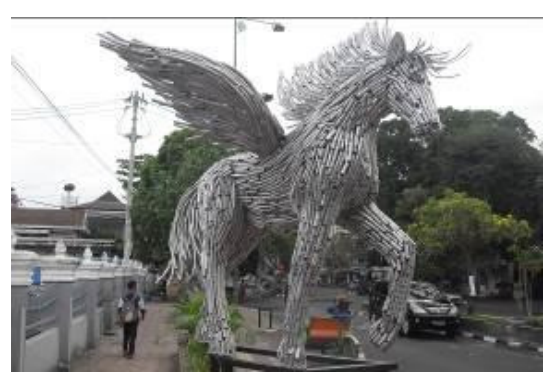

Figure 8. Kuda Egrang, craft work in Yogyakarta public space by Timbul Raharjo (Picture of personal documentation, 2015).

The emergence of talks among artists, academics and people about the presence of Kuda Egrang in the public space of Yogyakarta also deserves appreciation since one of the functions of public art is to activate dialogue among the citizens and provide a means for the whole city community to voice their opinions and express their identity.

\section{Conclusion}

Craft works that exist in the public space both abroad and in Indonesia, especially the city of Yogyakarta proved to be a positive tool both for the creator and audience and citizens as a medium of expression, voicing opinions, means of interaction, enhancer artistic taste and identity markers of the city, in addition to the practical functional aspects that are owned by 
the craft such as street furniture in the park or urban public space.

For audiences or craft art lovers who are citizens as well as visitors, the presence of artwork creations can enhance and train the sensitivity and sense to love and appreciate an art object, in this case craft art. Citizens, from the lower to the middle layer, old and young are also educated by the existence of existing artworks and become more literate to craft art (craft art awareness). They become more appreciative to the profession of the craft-person with all their works, love the culture, understand their own identity and are trained to maintain the work of craft arts that exist by not doing damage or conducting vandalism activities towards the craft art.

It is generally known that beautiful and correlated artworks with the surrounding environment can make the soul and feeling of a person become more subtle, sensitive and automatically able to filter things that are good for themselves. The citizens become civilized people because the city is able to become an air-conditioning oasis in the middle of the dry and tough life through artworks of intelligent, artistic, distinctive, innovative, and sensitive work in the environment.

\section{References}

Becker, J. (2010). An Essential Component of Creativity Communities. Retrieved on October 9, 2015. www. americanforthearts.org

Fleeming, R. L. (2007). The Art of Place- making. Interpreting Community Through Public Art and Urban Design. London: Merrell Publishers Limited.

Hartoko, D. (1984). Manusia dan Seni. Yogyakarta: Penerbit Kanisius.

Jazuli, M. (2014). Sosiologi Seni. Pengantar dan Model Studi Seni. Yogyakarta : Graha Ilmu.

Knox, G. (2013). Crafting A Continum: What Is Enduring in Craft? What is its Future? dalam Peter Held, ed. Crafting a Continuum. Rethinking Contemporary Craft. Temple: Arizona State University Art Museum.

Lufiani, A. (2016). Karya Kriya Seni di Ruang Publik Perkotaan. Makalah Seminar Nasional Hasil Riset inovatif. Institut Seni dan Budaya Bandung.

Puspitasari, D. G., Sabana, S., \& Ahmad, H. A. (2016). The Cultural Identity of Nusantara in a Movie Entitled Sang Pencerah by Hanung Bramantyo. Harmonia : Journal of Arts Research and Education, 16(1), 57-65.

Rohidi, T. R. (2015). CatatanRingkasTentangPotensidan Tantangan Pengembangan Seni Warisan Nusantara dalam proceeding $4^{\text {th }}$ International Seminar of Nusantara Heritage, UPSI, Malaysia.

Shankar, R. (2008). Jugaad Canopy. Public Art Installation, India. Retrieved on April 22, 2016. www.rajeevshankar. com/jugaad.

Wadiyo. (2006). Seni Sebagai Sarana Interaksi Sosial. Harmonia : Journal of Arts Research and Education, 7(2), 72-79. 